\title{
The Sticherarion of Hieromonk Macarie (Ms. Bar 1690)
}

\section{Florian Mircea PĂDUREAN*}

Abstract: Hieromonk Macarie is one of the reforming worthy persons of our church music who adapted the songs according to the Romanian taste, its compositions being characterized by simplicity, clarity and sweetness. The Sticherarion, given to the Library of the Romanian Academy by Moldova Metropolitan Iosif Naniescu, is part of the work of Macarie, remaining in the manuscript and is a Greek translation of the Anthology of Sticherarion, by Gregory Protopsaltes, who, with Hurmuz Hartofilax, transposed in the new graphy the Sticherarion of Chrysaphes the New in the seventeen century. The songs in this work, written in argon style, are broadly addressed to all religious people who have reached a hot stage of prayer that falls within the rigors of time.

Keywords: Sticherarion, stichera, idiomelon, manuscript, melos, Hieromonk Macarie, Gregory Protopsaltes, Chrysaphes the New.

\section{Sticherarion. Stichera. Sticheraric}

The Sticherarion is a book that includes the stichera for morning and evening sermons throughout the church year.

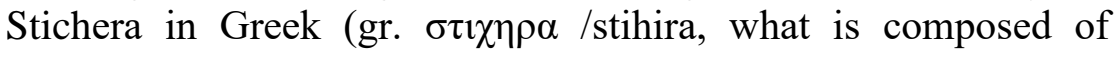
„styhos") is a troparion preceded by a styhos used in the day's

* PhD, „Isidor Todoran” PhD School Faculty of Orthodox Theology at „BabeșBolyai" University, Cluj- Napoca, Romania. 
sermons. These troparia can be found in the books of Mina, Octoechos, Triodion, Catavasier, books that support, maintain the public divine worship in the Orthodox Church. In Greek, $\sigma \tau \imath \chi \eta \rho o v$ may mean which is in connection with a verse $(\sigma \tau \imath \chi)$.

So, the book called Sticherarion, groups the songs that are played alternately with the styhos of the Psalms.

In Sticherarion, Anatolian sticheras, Sticheras of Anatolie ${ }^{1}$, Dogmatic Theotokion, Sticheras from Stihoavna and Eothinas can be met. The Sticherarion melos is most often used for singing sticheras, but not exclusively, being split in fast and slow. All the songs of Vespers and Orthros, preceded by a styhos of psalms belong to syntomon Sticherarion, while argon Sticherarion, all the types of post-Byzantine idiomela ${ }^{2}$ and especially the ,glories", widely sung, from the solemn sermons of the various holidays, as they appear in the ,abridged Doxastarion” by Iakobos Protopsaltes (translated by Chourmouzios Chartophylax and Gregory Protopsaltes) and in the manuscripts of Chourmouzios Chartophylax, belong to syntomon Sticherarion.

About the Sticheraric style, Byzantinologist Grigore Panţîru, referring to Western music, says that the andantino movement corresponds to the andantino movement ${ }^{3}$.

Referring to the composition of church songs, to the sticheraric melos, Georgios N. Konstantinou, professor at the

${ }^{1}$ Ene BRAnIŞTE, General Liturgy, vol. I., Galați, Publishing House of Dunarea de Jos Episcopate, 2002, p. 321.

2 Idiomelon (gr.1 $\delta 10 \mu \varepsilon \lambda \mathrm{ov}$ ), is a troparion-shaped hymn with text in prose, which has its own, non-borrowed song; does not serve as a model for other singings. It is sometimes composed of several stanzas, even non-similar and placed on different melodies - Dictionary of musical terms, scientific and encyclopedic printing, Bucharest, 1984, p. 234.

${ }^{3}$ Grigore PANȚîRU, The Notation and the ihos of Byzantine Music, Bucharest, The Musical Publishing House of the Union of Composers, 1971, p. 203. 
State Conservatory of Athens, calls sticherarics ${ }^{4}$ those idiomela of Vespers and Orthros, distinct from the troparia, short hymns, sedalens, heirmoi kalophonikon, the anixandaria of Irmologion, respectively from the irmological melos, as they have their own melody. In the sticheraric singing, two or more melos times correspond to a syllable, the syllable containing three or more accents and cadences.

Sticheraric idiomela are divided into ${ }^{5}$ :

- the idiomela preceded by a styhos of psalms.

- the idiomela that preceded the small doxology: „Glory to the Father ..." and which are sung at the slowest rhythm of all idiomela that are preceded by styhos.

The chants present in Hieromonk Macarie's Sticherarion, are part of the old Sticherarion of Crysaphes the New, who in 1670 composed these chants in new musical byzantine notation system of byzantine music.

\section{Chrysaphes the New (Manuil Chrysaphes the Young)}

Byzantine music teacher Nicolae Gheorghita, from the National University of Music in Bucharest, dividing the period of Turcocracy (from the fall of Constantinople to the Greek Revolution) - in five epochs, says that the first great personality and the greatest composer of the period 1670- 1740 was Chrysaphes the New $(\sim 1650-1685)^{6}$, the protopsaltes of the Great Church, whose major contribution was to both

${ }^{4}$ Georgios N. Konstantinou, Theory and practice of church music, translated into romanian by Adrian Sîrbu, Byzanton cultural Association, Iași 2012, p. 92.

${ }^{5}$ Ibidem, p. 93.

${ }^{6}$ Nicolae GHEORGHIȚĂ, Sunday Chinonic in the post-Byzantine period 14531821, Sofia Publishing House, Bucharest, 2009, p. 35. 
Anastasimatar's repertoire as well as that of the Old Sticherarion proposed by Manuel Chrysaphes the Lampadar .

Chrysaphes the New conducted a rich teaching and compositional activity, remarking himself in the first ranks of 17thcentury psalmist musicians alongside Balasie the Priest, Ghermano Neon Patron ${ }^{7}$, and Iovascu Vlach. Byzantineologist Gheorghe C. Ionescu states that Chrysaphes the New visited Wallachia and, after some appreciation, ,he would have stayed here for a long time contacting the Romanian Musical School at the Court of Constantin Brâncoveanu", and Father Archdeacon Sebastian Barbu-Bucur published a Polihronion written by Chrysaphes in honor of this ruler, saying, ,He will sing when he raises a glass for

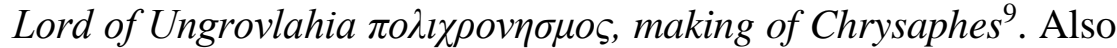
Arch. Sebastian Barbu-Bucur, investigating between 1982 and 1985 the Romanian and Greek musical manuscripts written by the Romanians for Romanians in the Holy Mountain, discovered three manuscripts, all in the Library of the Romanian Library of Chinovi, Podromu -Athos, who would first reveal his ethnic origin and in which Chrysaphes the New met the names of „Chrysaphes

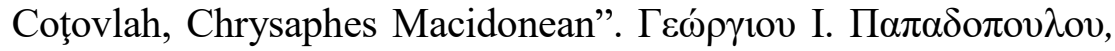

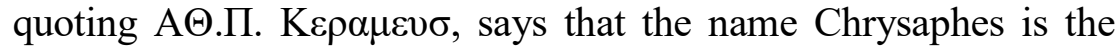
main name, received at baptism, the Chrysaphes sign of Gaza,

${ }^{7}$ Sebastian BARBU-BuCUR, Filothei sin Agăi Jipei. Romanian psalm book, vol.III, The sticherarion in: Sources of the Romanian music. Documenta et Transcripta, vol. VII C, Bucharest, Musical Publishing, 1986, p. 14.

${ }^{8}$ Gheorghe C. IONESCU, The lexicon of those who over the centuries dealt with Byzantine music in Romania, Bucharest, Diogene Printing, 1994, p. 166.

9 Sebastian BARBU-BuCUR, Presumptions about the new origin of Hrisafi's ethnic origin, in Acta Musicae Byzantinae, vol. III, April 2001, Iași, Center for Byzantine Studies, p. 79-83. 
which is one and the same with Chrysaphes the New one ${ }^{10}$ once was found in a manuscript from 1777.

In 1660 Manuel Chrysaphes the New, was in the prime of life. He composed besides cherubikons, axions, chinonic, polyeleos, doxologies, heirmoi kalophonikon, pasapnoaria, kratima, and the Palaion and the Argon of Anastasimatarion and the Palaion and the Argon of Sticherarion, in which he has lessons and the contemporary one with him Bartholomew the Monah, the domestikos of the Holy Lavra Monastery, in the Holy Mountain.

In the Library of the Romanian Academy there are several copies - manuscript of the Sticherarion of Chrysaphes the New:

$$
\text { Ms.gr.1499 BAR - Sticherarion-Triodion- }
$$

Pentecostarion (sizes: $227 \times 155 \mathrm{~mm}$; files: 437; date: end of the 17th century)- volume-model of Chrysaphes the New ${ }^{11}$.

- Ms.gr.899 BAR- Sticherarion-Triodion-Pentecostarion (sizes: $167 \times 106 \mathrm{~mm}$; files: 425; date: end of the 17th century) ${ }^{12}$.

- Ms. gr. 41 BAR- Sticherarion-Triodion-Pentecostarion (sizes: $208 \times 154 \mathrm{~mm}$; files: 159; date: 17-18th century) ${ }^{13}$.

There is also a copy of the Sticherarion-Triodion Penticostarion, of Chrysaphes the New, in the Library of the Stavropoleos Monastery, namely the 47th Manuscript. The Sticherarion of Chrysaphes the New penetrated the new graf by Greek tradition being explained in an Anthology, by Gregory Protopsaltes and Hurmuz Hartofilax, romanianised by Hieromonk Macarie, calligraphized by his command and expense, by Ilie the Singer of St. Nicolae-Vladica Church from Bucharest in 1825.

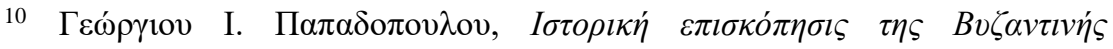

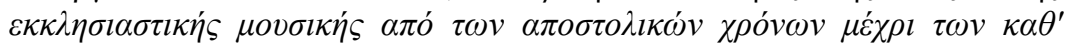

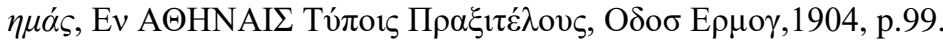

11 Ozana ALEXANDRESCU, The catalog of 17th-century Byzantine musical manuscripts, Bucharest, Arvin Press Publishing House, 2005, p. 118.

${ }^{12}$ Ibidem, p. 159.

${ }^{13}$ Ibidem, p. 175. 


\section{Gregory Protopsaltes}

Gregory Protopsaltes was one of the three reformers who, in the 19th century, brought to light the „New Method" that was imposed after the 1814 reform.

The activity of the three-Gregory the Protopsaltes, Hrisant of Madit and Hurmuz Hartofilax -consisted of the simplification of musical signs, and the introduction of the notation system of the Neo-Byzantine music on which the current songs are based.

It is not known exactly the year of the birth of Gregory Protopsaltes. The tradition imposes the year 1778 on the day of the death of Peter Lambadarie, the Peloponnese. His father, Gheorghe, was a priest and his mother was called Elena. His death lies between 1820 and 1822 . Musicologists tend to regard it as taking place in December 1821.

From his youth, he taught Armenian language and music, because he liked to go to the Armenian Church. At the Sinai Metropolis of Valata, Gregory taught the Greek and, due to his beautiful voice, he became Reader and then Chanter.

His masters were Iakobos Protopsaltes, Petru Vizantie Protopsaltes and George the Cretan. At the time when Peter Vizantie was Protopsaltes, between 1800 and 1805, Gregory was also at the Ecumenical Patriarchate, though not as Lambadarios, at least as Domestic. Then, around 1810, Gregory was the Lambadarios of Manuil Protopsaltes. From Lambadarios, Gregory became Protopsaltes after Manuel's death on June 21, 1819. As Archcantor, he chanted for two and a half years until his death in December 1821. He was not in this service until about two years and half. Between 1800-1805, Gregory married and had children, but we do not know exactly how many. Constantin Psachos talks about the last daughter of Gregory, who in 1897 was 90 years old. 
Gregory Protopsaltes's work can be divided into three categories ${ }^{14}$ :

Own compositions:

- Polyeleos „Servants of the Lord” and Polyeleos „At the Babylon River";

- 3 series of cherubic hymns, number 24, small, medium and very large;

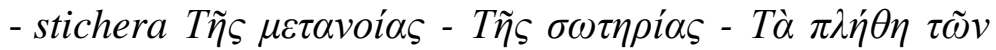
$\pi \varepsilon \pi \rho \alpha \gamma \mu \varepsilon \dot{v} \omega v$ ног $\delta \varepsilon l v \tilde{\omega} v$.

- troparia of the Hours;

- Sunday communion songs and of the usual days;

- „Lord, you have mercy on us” in the plagal modes;

- Song on the dress of the arhiereu when he is dressed as

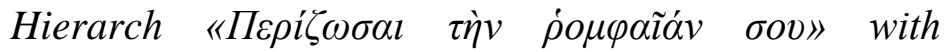
kratima;

- the psalm 50 in mode II;

- 4 doxologies in the plagal modes;

- the traditional melody of the Apostle and Gospel readings in mode $I V$;

- The Divine Liturgy in IV mode legetos;

- axions in the number of 16;

- Kratima, prokeimena on days and holidays, and others;

Explanatory papers:

Gregory explained and transcribed in the new notation the following works of melodies, especially those of the 17th and 18th centuries:

- all the works of Petru Bereketis (4 volumes).

- the Sticherarion of Ghermanos Neon Patron (5 volumes).

14 Ecumenical Patriarchate, Gregory Protopsaltes the Byzantios, http://www.ec-patr.net/en/history/gregory-byzantios.htm (accesat la data de 06.03.2019). 
- papadikia of Peter Byzantios (5 volumes).

- irmologion kalophonic (1 volume).

- Anastasimatarion of Peter the Peloponnesian (1 volume).

- Peter Peloponnesian irmologion (1 volume).

- Petru Byzantie 's short speech (1 volume).

- The Doxastarion of Peter Byzantie (2 volumes)

- Anthology of the Sticherarion of Chrysaphes the New;

Secular songs (non-church songs):

He also wrote about 30 songs similar to Turkish makams.

In the manuscript, many of his compositions have as a subtitle the note that the song is "as it is sung in the Great Church of Christ. Some of his songs are included in the Euterpe and Pandora collections.

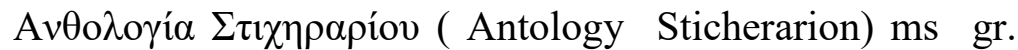
1945 of Gregory Protopsaltes with which the Sticherarion of Hieromonk Macarie will be compared, is located in the National

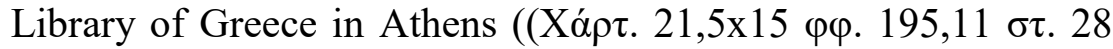

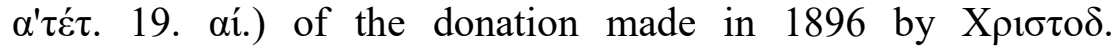

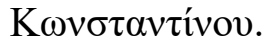

As we can see, it is an Anthology of songs, not a complete translation of the old Sticherarion of Chrysaphes the New.

\section{Hieromonk Macarie}

Hieromonk Macarie was born around the year $1770^{15}$. He entered as a young man in the monastic life. He was introduced in the mysteries of singing by Constandin, the Protopsaltes of the Royal Court, the new semiography, studying it at Petru Efesiu's school. He was a teacher of the first music school in the new Romanian language notation, founded in Bucharest in 1819, and administrator (inspector) over the 15 schools of singers from

15 Gheorghe C. IONESCU, op.cit., p. 212. 
Wallachia, starting with 1825. In 1829 he left for Moldova, where he was abbot of Bârnova Monastery, then leader of the Neamţ Monastery School. In 1834 he returned to Căldăruşani, being the printing press-corrector, then the manager of the Printing House, until the summer of 1836, when he became seriously ill. He died in September 1836, at Viforâta Monastery, where he was buried.

Hieromonk Macarie (sometimes called the Singer) translated into Romanian and composed numerous songs in both the old and the new notation. Some of them were printed (church Anastasimatarion - Vienna, 1823, Church Heirmologion or Catavasier - Vienna, 1823, Second tomb of Anthology Bucharest, 1827, Passage of God -Buzau, 1836), others remained in the manuscript (Sticherarion, Irmologhion calofonicon, singings from Orthros and the Divine Liturgy, contained in the second, third and fourth volumes of Antologion).

The printing of Anastasimatarion was not easy ${ }^{16}$. In 1821, the revolution in Wallachia broke out. Macarie was left with no funds for printing, returned to Sibiu to seek financial support. At Sibiu he concluded a new contract with the owner of Hagi Pop House, Stan Popovici, convincing him that along with another Transylvanian, Gheorghe Oprean and stolnic Voicu, Macarie's brother, would finance the printing of 1500 copies of Theoriticon (now volume separate from Anastasimatarion), Anastasimatarion and Irmologion.

The three volumes published by Hieromonk Macarie in Vienna were the first prints of church music in the psaltic notation, in Romanian. He wanted to print them in special conditions:

„We are going to print the books on the first and the finest paper (...), even though it is twice more expensive than the leon, that our nation has been swamping in thick things, inappropriate things,

16 Costin MoIsIL, Anastasimatarion of Hieromonk Macarie - introductory study, Byzantine printing, Bucharest 2002, p. XIII. 
laughter and mockery being other nations. Modes, which are said to be in black, and the other signs, as ftorals, testimonies and gorges, to fall in red, with red, even though it is threefold expense. And because these books of psaltichia are not like other books, which year after year change, but remain forever in this settlement, we need to tie them with good bond, for entering the second time in the hands of the bonders there, it is impossible to remain uninterrupted, being the connection in this way: at the heel and at the corners of the skin, the hem with golden flowers is adorned, and the other faces of the macaws will be covered with paper just like the skin, both thick, to the face and to the living ..." 17.

The Sticherarion of Hieromonk Macarie is part of his work remaining in the manuscript. The Romanian Manuscript 1690 was given to the Library of the Romanian Academy in 1894, from the Metropolitan Library of Moldavia, Iosif Naniescu ${ }^{18}$. It contains 248 sheets. From the sheet 1 to the sheet 122 there is the first copy and from the sheet 123 until the end there is the second copy. So we are dealing with a manuscript that brings together two copies of the same Sticherarion of Hieromonk Macarie. The text of the songs as well as the name are written in black ink and titles, initials, ftorals, testimonies, with red ink. The size is $24 \times 18.5 \mathrm{~cm}$.

As shown in the first and last sheets of the Romanian manuscript 1690 from the Library of the Romanian Academy, it was made up of the Chrysaphes the New , exighisited by Gregory Protopsaltes and Hurmuz Hartofilax, prefaced on the Romanian language by Hieromonk Macarie and written by Ilie the Singer:

„first on his old one made by the blessed man in the memory of Chrisaphes the New. And on the new musical byzantine notation system of byzantine music or explained by Gregory Protopsaltes of

${ }^{17}$ Ibidem, p. XIV.

18 Gabriel ȘTREMPEL, The catalog of Romanian manuscripts B.A.R. 1601 3100, vol II, Scientific printing, Bucharest, 1983, p. 156. 
God's Sacred Great Church. And by Hurmuz Hartofilax, the founder of this new musical byzantine notation system of byzantine music, and on our Romanian language or translated by the humble Hieromonk Macarie of the Holy Mitropoly, the teacher of the Romanian music schools in 1825, September 1" 19 .

„I wrote this Sticherarion by myself: Ilie the Singer of the Church of Saint Hierarch Nicholas, Mahalaua Vlădicăi, with the command and expense of His Holiness Father Hieromonk Macarie, the teacher of the Romanian musical schools" 20 .

Ilie the singer is one and the same person known as Ilie Stoianovici-Jianu. In the first half of the nineteenth century, he was a singer at Maica Precista - Mântuleasa Church in Craiova, and at St. Nicholas Church in Vlădichii Mahalla near the patriarchal cathedral in Bucharest, in 1822. In 1827 he returned to Craiova, to the Madona Dudu church and Obedeanu church.

At the request of Hieromonk Macarie, in 1825, he writes two of his works translated from Greek, The Sticherarion (Romanian manusc. 1690 B.A.R.), and Papadikia, explained by Gregory Protopsaltes, and by Hurmuz Hartofilax (Romanian manusc. 1691 B.A.R $)^{21}$.

\section{Manusc. EBE 1945. / Romanian manusc. BAR.1690 - contents}

The Sticherarion of Hieromonk Macarie and Sticherarion Anthology of Gregory Protopsaltes, have the following:

\section{The Sticherarion of Hieromonk Macarie \\ The Sticherarion -Anthology of Gregory Protopsaltes}

19 The Romanian Manuscript 1690, Library of the Romanian Academy, f. 1.

${ }^{20}$ Ibidem, p. 122.

${ }^{21}$ Gheorghe C. IONESCU, op. cit., p. 174. 


\begin{tabular}{|c|c|}
\hline Manuscript BAR 1690 & Manuscript EBE 1945 \\
\hline $\begin{array}{l}\text { Dogmatic Theotokion mode. I, } \\
\text { f. 1- 4, page. 1- 7; }\end{array}$ & $\begin{array}{l}\text { Dogmatic Theotokion mode. I, } \\
\text { f. } 1-5 \mathrm{v} \text {, page. } 1-10 ;\end{array}$ \\
\hline $\begin{array}{l}\text { Dogmatic Theotokion mode II, } \\
\text { f. } 4-5 \mathrm{v}, \text { p. } 7-10 ;\end{array}$ & $\begin{array}{l}\text { Dogmatic Theotokion mode II, } \\
\text { f. } 5 \mathrm{v}-8 \mathrm{v}, \text { p. } 10-16 ;\end{array}$ \\
\hline $\begin{array}{l}\text { Dogmatic Theotokion mode. } \\
\text { III, f. } 5 \mathrm{v}-8 \text {, p. } 10-15\end{array}$ & $\begin{array}{l}\text { Dogmatic Theotokion mode III, } \\
\text { f. } 8 \mathrm{v}-12 \mathrm{v}, \text { p. } 16-24 ;\end{array}$ \\
\hline $\begin{array}{l}\text { Dogmatic The } \\
\text { IV, f. } 8-11\end{array}$ & $\begin{array}{c}\text { Dogmatic Theotokion mode IV, } \\
\text { f. } 12 \mathrm{v}-17 \text {, p. } 24-33 ;\end{array}$ \\
\hline $\begin{array}{l}\text { Dogmatic Theotokion } \mathrm{p} \\
\text { mode I, f. } 11-13 \text {, p. } 21\end{array}$ & $\begin{array}{l}\text { Dogmatic Theotokion plagal } \\
\text { mode I, f. } 17-21 \text {, p. } 33-41 \text {; }\end{array}$ \\
\hline $\begin{array}{l}\text { Dogmatic Theotokion plagal } \\
\text { mode II, f. } 13 \mathrm{v}-15 \mathrm{v} \text {, p. } 26-30 \text {; }\end{array}$ & $\begin{array}{l}\text { Dogmatic Theotokion plagal } \\
\text { mode II, f. } 21-24 \text {, p. } 41-47 \text {; }\end{array}$ \\
\hline $\begin{array}{l}\text { Dogmatic Theotokion plagal } \\
\text { mode III, f.15v - 17v, p. } 30- \\
34 ;\end{array}$ & $\begin{array}{l}\text { Dogmatic Theotokion plagal } \\
\text { mode III, f. } 24 \mathrm{v}-27 \mathrm{v}, \text { p. } 48 \text { - } \\
54 ;\end{array}$ \\
\hline $\begin{array}{l}\text { Dogmatic Theotokion plagal } \\
\text { mode IV, f. } 17 \mathrm{v}-20 \text {, p. } 34-39 \text {; }\end{array}$ & $\begin{array}{l}\text { Dogmatic Theotokion plagal } \\
\text { mode IV, f. } 27 \mathrm{v}-31 \mathrm{v}, \text { p. } 54- \\
62 ;\end{array}$ \\
\hline $\begin{array}{l}\text { The beginning with the holy } \\
\text { God of the eleven eothinas } \\
\text { who from the beginning were } \\
\text { made up by the blessed John } \\
\text { the Sweet: } \\
\text { Eothina I, f. } 20-22, \text { p. } 39-43 \text {; }\end{array}$ & $\begin{array}{l}\text { Eothina I, f. } 31 \mathrm{v}-34 \mathrm{v}, \text { p. } 62- \\
68 ;\end{array}$ \\
\hline Eothina II, f. 22 - 24, p. 43 - 47; & Eothina II, f. 35 - 38, p. 69 - 75; \\
\hline Eothina III, f. 24 - 26v, p. 47 - & Eothina III, f. 38 - 42, p. 75 - \\
\hline
\end{tabular}




\begin{tabular}{|c|c|}
\hline 52 & 83; \\
\hline $\begin{array}{l}\text { Eothina IV, f. } 26 \mathrm{v}-29, \text { p. } \\
57\end{array}$ & $\begin{array}{l}\text { Eothina IV, f. } 42-46, \text { p. } 83 \text { - } \\
91 ;\end{array}$ \\
\hline Eothina V, f. 29 - 32, p. 57 - 63; & $\begin{array}{c}\text { Eothina V, f. } 46-51 \text {, p. } 91 \text { - } \\
101 ;\end{array}$ \\
\hline $\begin{array}{l}\text { Eothina VI, f. } 32 \text { - 34v, p. } 63 \text { - } \\
68 ;\end{array}$ & $\begin{array}{l}\text { Eothina VI, f. } 51 \text { - 55, p. } 101 \text { - } \\
109 ;\end{array}$ \\
\hline $\begin{array}{c}\text { Eothina VII, f. } 34 \mathrm{v}-36 \text {, p. } 68 \text { - } \\
71 ;\end{array}$ & $\begin{array}{c}\text { Eothina VII, f. } 55 \text { - 57v, p. } 109 \\
-114 ;\end{array}$ \\
\hline $\begin{array}{c}\text { Eothina VIII, f. } 36-38 \mathrm{v}, \text { p. } 71- \\
76 ;\end{array}$ & $\begin{array}{c}\text { Eothina VIII, f. } 57 \mathrm{v}-62 \text {, p. } 114 \\
-123 ;\end{array}$ \\
\hline $\begin{array}{l}\text { Eothina IX, f. } 38 \mathrm{v}-40 \mathrm{v}, \text { p. } 76- \\
80 ;\end{array}$ & $\begin{array}{l}\text { Eothina IX, f. } 62-67, \text { p. } 123- \\
133 ;\end{array}$ \\
\hline $\begin{array}{c}\text { Eothina } \mathrm{X}, \mathrm{f} .40 \mathrm{v}-43, \mathrm{p} . \\
85 ;\end{array}$ & $\begin{array}{c}\text { Eothina X, f. } 67-71, \text { p. } 133- \\
141 ;\end{array}$ \\
\hline $\begin{array}{c}\text { Eothina XI, f. } 43 \text { - 46, p. } 85 \text { - } \\
91 ;\end{array}$ & $\begin{array}{c}\text { Eothina XI, f. 71v - 77v, p. } 142 \\
-154 ;\end{array}$ \\
\hline $\begin{array}{l}\text { The Hours of the Birth of God } \\
\text { and our Savior Jesus Christ of } \\
\text { The Old Sticherarion }\end{array}$ & $\begin{array}{c}\text { The Hours of the Birth of God } \\
\text { and our Savior Jesus Christ of } \\
\text { The Old Sticherarion }\end{array}$ \\
\hline $\begin{array}{c}\text { Hour I: } \\
\text { Vitleem prepare yourself } \\
\text {...plagal mode IV, f. } 46-47 \mathrm{v} \\
\text { p. } 91-94 ;\end{array}$ & $\begin{array}{c}\text { Hour I: } \\
\text { Vitleem prepare yourself ........ } \\
\text { plagal mode IV, f. } 77 \mathrm{v}-80, \text { p. } \\
154-159 ;\end{array}$ \\
\hline $\begin{array}{l}\text { Now prophesy of the } \\
\text { prophets.... mode III, f. 47v - } \\
\text { 49, p. } 94 \text { - 97; }\end{array}$ & $\begin{array}{l}\text { Now prophesy of the } \\
\text { prophets.... mode III, f.80-82, } \\
\text { p. } 159-163 \text {; }\end{array}$ \\
\hline
\end{tabular}




\begin{tabular}{|c|c|}
\hline $\begin{array}{c}\text { Glory....and now...: } \\
\text { Iosif says these....plagal mode } \\
\text { IV, f. } 49-51, \text { p. } 97-101\end{array}$ & $\begin{array}{c}\text { Glory....and now...: } \\
\text { Iosif says these....plagal mode } \\
\text { IV, f.82 - 85v, p. } 163-170\end{array}$ \\
\hline $\begin{array}{l}\text { The third hour: } \\
\text { This is our God....plagal mode } \\
\text { II, f. } 51-52 \mathrm{v}, \text { p. } 101-104\end{array}$ & $\begin{array}{c}\text { The third hour: } \\
\text { This is our God....plagal mode } \\
\text { II, f. } 85 \mathrm{v}-88, \text { p. } 170-175 \text {; }\end{array}$ \\
\hline $\begin{array}{l}\text { Before Your Birth ....plagal } \\
\text { mode IV, f. 52v - 54, p. } 104 \text { - } \\
107 ;\end{array}$ & $\begin{array}{l}\text { Before Your Birth ........plagal } \\
\text { mode IV, f. } 88 \text { - 90v, p. } 175 \text { - } \\
180 ;\end{array}$ \\
\hline $\begin{array}{c}\text { Glory....and now...: Iosif tell } \\
\text { us....mode III, f. } 54 \text { - 55, p. } 107 \\
\text { - 109; }\end{array}$ & $\begin{array}{l}\text { Glory.... and now...: Iosif tell } \\
\text { us....mode III, f. } 90 \mathrm{v}-92 \mathrm{v}, \mathrm{p} . \\
180-184 ;\end{array}$ \\
\hline $\begin{array}{l}\text { The sixth hour: } \\
\text { Come on christians to ascend.... } \\
\text { mode I, f. } 55 \mathrm{v}-57, \text { p. } 110- \\
113 ;\end{array}$ & $\begin{array}{l}\text { The sixth hour: } \\
\text { Come on christians to ascend.... } \\
\text { mode. I, f. } 92 \mathrm{v}-95 \mathrm{v}, \text { p. } 184- \\
190 ;\end{array}$ \\
\hline $\begin{array}{l}\text { You sky hear and you earth } \\
\text { listen.... } \\
\text { mode IV, f. } 57 \mathrm{v}-58 \mathrm{v}, \text { p. } 113 \text { - } \\
116 ;\end{array}$ & $\begin{array}{l}\text { You sky hear and you earth } \\
\text { listen.... } \\
\text { mode IV, f. } 95 \mathrm{v}-98 \text {, p. } 190 \text { - } \\
195 ;\end{array}$ \\
\hline $\begin{array}{l}\text { Glory... and now...: } \\
\text { Come, you crowds of the Christ } \\
\text { carrying...plagal mode I, f. } 58 \mathrm{v} \\
\text { - } 60 \mathrm{v}, \text { p. } 116-120 ;\end{array}$ & $\begin{array}{l}\text { Glory... and now...: } \\
\text { Come, you crowds of the Christ } \\
\text { carrying...plagal mode I, f. } 98 \text { - } \\
101 \mathrm{v}, \text { p. } 195-202 ;\end{array}$ \\
\hline $\begin{array}{l}\text { The nineth hour: } \\
\text { Herod was frightened.... plagal } \\
\text { mode III, } \\
\text { f. } 60 \mathrm{v}-62 \text {, p. } 120-123\end{array}$ & $\begin{array}{l}\text { The nineth hour: } \\
\text { Herod was frightened....plagal } \\
\text { mode III, } \\
\text { f. } 101 \mathrm{v}-104, \text { p. } 202-207 ;\end{array}$ \\
\hline When Joseph Fecioara with & When Joseph Fecioara with \\
\hline
\end{tabular}




\begin{tabular}{|c|c|}
\hline $\begin{array}{l}\text { sorrow was hurt.... mode II, f. } \\
\quad 62-64, \text { p. } 123-127\end{array}$ & $\begin{array}{l}\text { sorrow was hurt.... mode II, f. } \\
104-107 \mathrm{v}, \text { p. } 207-214 ;\end{array}$ \\
\hline $\begin{array}{l}\text { Glory.. and now...: } \\
\text { Today he is born by Mary, } \\
\text { mother of Jesus....plagal mode } \\
\text { II, f. } 64 \mathrm{v}-66, \text { p. } 128-131\end{array}$ & $\begin{array}{l}\text { Glory.. and now...: } \\
\text { Today he is born by Mary, } \\
\text { mother of Jesus....plagal mode } \\
\text { II, f. } 108-111, \text { p. } 215-221 \text {; }\end{array}$ \\
\hline $\begin{array}{l}\text { The Hours of Saint Baptism } \\
\text { in the Sticherarion the old }\end{array}$ & $\begin{array}{l}\text { The Hours of Saint Baptism } \\
\text { in the Sticherarion the old }\end{array}$ \\
\hline $\begin{array}{l}\text { First Hour: } \\
\text { Today the nature of the } \\
\text { waters....plagal mode IV, f. } 66 \text { - } \\
66 \mathrm{v}, \text { p. } 131-132 ;\end{array}$ & $\begin{array}{l}\text { First Hour: } \\
\text { Today the nature of the } \\
\text { waters...plagal mode IV, f. } 111 \\
-112, \text { p. } 221-223 ;\end{array}$ \\
\hline $\begin{array}{c}\text { Like a man at the river... plagal } \\
\text { mode IV, f.66v - 67v, p. } 132- \\
134 ;\end{array}$ & $\begin{array}{l}\text { Like a man at the river... plagal } \\
\text { mode IV, f.112- } 113 \mathrm{v}, \text { p. } 223- \\
226 ;\end{array}$ \\
\hline $\begin{array}{l}\text { Glory...and now...: } \\
\text { To the voice of the one } \\
\text { crying...plagal mode IV, } \\
\text { f.67v - 69, p. 134- 137; }\end{array}$ & $\begin{array}{c}\text { Glory...and now...: } \\
\text { To the voice of the one } \\
\text { crying...plagal mode IV, } \\
\text { f.113v - } 116 \mathrm{v}, \text { p. } 226-232 \text {; }\end{array}$ \\
\hline $\begin{array}{c}\text { Third hour : } \\
\text { To the walker straight } \\
\text { on.....plagal mode IV, } \\
\text { f. } 69-70 \mathrm{v}, \text { p. } 137-140\end{array}$ & $\begin{array}{c}\text { Third hour : } \\
\text { To the walker straight } \\
\text { on....plagal mode IV, } \\
\text { f. } 116 \mathrm{v}-119, \text { p. } 232-237 \text {; }\end{array}$ \\
\hline $\begin{array}{l}\text { Trinity, our God......mode IV, f. } \\
\text { 70v - 72, p. } 140-143 ;\end{array}$ & $\begin{array}{l}\text { Trinity, our God...mode IV, f. } \\
119-121 \mathrm{v}, \text { p. } 237-242 ;\end{array}$ \\
\hline $\begin{array}{l}\text { Glory...and now...: } \\
\text { Coming with the body to the } \\
\text { Jordan....plagal mode I, } \\
\text { f. } 72-73 \mathrm{v}, \text { p. } 143-146 ;\end{array}$ & $\begin{array}{l}\text { Glory... and now...: } \\
\text { Coming with the body to the } \\
\text { Jordan ....plagal mode I, } \\
\text { f. } 121 \mathrm{v}-124 \text {, p. } 242-247 \text {; }\end{array}$ \\
\hline
\end{tabular}




\begin{tabular}{|c|c|}
\hline $\begin{array}{c}\text { The sixth hour : } \\
\text { This is what the Lord says to } \\
\text { John.... } \\
\text { plagal mode IV, f. } 73 \mathrm{v}-75 \mathrm{v}, \mathrm{p} \text {. } \\
146-150 ;\end{array}$ & $\begin{array}{l}\text { The sixth hour : } \\
\text { This is what the Lord says to } \\
\text { John.... } \\
\text { plagal mode IV, f. } 124-127 \mathrm{v}, \mathrm{p} \text {. } \\
247-254 ;\end{array}$ \\
\hline $\begin{array}{l}\text { Today the psalm prophecy.... } \\
\text { plagal mode II, f. } 75 \mathrm{v}-76 \mathrm{v}, \mathrm{p} \text {. } \\
150-152 ;\end{array}$ & $\begin{array}{c}\text { Today the psalm prophecy.... } \\
\text { plagal mode II, f. } 127 \mathrm{v}-129 \mathrm{v}, \\
\text { p. } 254-258 ;\end{array}$ \\
\hline $\begin{array}{l}\text { Glory....and now...: } \\
\text { Why you turn your waters.... } \\
\text { plagal mode I, f. } 76 \mathrm{v}-79, \mathrm{p} . \\
152-157 ;\end{array}$ & $\begin{array}{l}\text { Glory....and now...: } \\
\text { Why you turn your waters.... } \\
\text { plagal mode I, f. 129v - 133v, p. } \\
258-266 ;\end{array}$ \\
\hline $\begin{array}{c}\text { The nineth hour : } \\
\text { It was scary to see the Maker... } \\
\text { plagal mode III, f. } 79-80, \text { p. } \\
157-159 ;\end{array}$ & $\begin{array}{c}\text { The nineth hour : } \\
\text { It was scary to see the Maker... } \\
\text { plagal mode III, f. } 133 \mathrm{v}-135 \text {, } \\
\text { p. } 266-269 ;\end{array}$ \\
\hline $\begin{array}{l}\text { When he saw the Walker } \\
\text { before... mode II, f. 80- 82, p. } \\
159-163\end{array}$ & $\begin{array}{l}\text { When he saw the Walker } \\
\text { before....mode II, f. } 135-138 \mathrm{v} \text {, } \\
\text { p. } 269 \text { - } 276 ;\end{array}$ \\
\hline $\begin{array}{l}\text { Glory.... and now...: } \\
\text { Your hand that touched.... } \\
\text { plagal mode I, f. } 82-84, \text { p. } 163 \\
\text { - } 167 ;\end{array}$ & $\begin{array}{l}\text { Glory.... and now...: } \\
\text { Your hand that touched.... } \\
\text { plagal mode I, f. 138v - 142, p. } \\
276-283 ;\end{array}$ \\
\hline $\begin{array}{c}\text { In Holy and Great Friday, in } \\
\text { the Hours of the Holy } \\
\text { Passions, in The Old } \\
\text { Sticherarion }\end{array}$ & $\begin{array}{c}\text { In Holy and Great Friday, in } \\
\text { the Hours of the Holy } \\
\text { Passions, in The Old } \\
\text { Sticherarion }\end{array}$ \\
\hline $\begin{array}{l}\text { First Hour: } \\
\text { Today the church's }\end{array}$ & $\begin{array}{c}\text { First Hour: } \\
\text { Today the church's }\end{array}$ \\
\hline
\end{tabular}




\begin{tabular}{|c|c|}
\hline $\begin{array}{l}\text { iconostasis...plagal mode IV, } \\
\text { f. } 84 \mathrm{v}-85, \text { p. } 168-169 ;\end{array}$ & $\begin{array}{l}\text { iconostasis...plagal mode IV, } \\
\text { f. } 142-143, \text { p. } 283-285\end{array}$ \\
\hline $\begin{array}{l}\text { Like a sheep for slaughter.... } \\
\text { plagal mode IV, f.85 - 86, p. } \\
\qquad 169-171\end{array}$ & $\begin{array}{l}\text { Like a sheep for slaughter.... } \\
\text { plagal mode IV, f.143 - 144, p. } \\
\qquad 285 \text { - } 287 ;\end{array}$ \\
\hline $\begin{array}{l}\text { Glory...and now...: God } \\
\text { enduring all... plagal mode IV, } \\
\text { f. } 86 \text { - } 88, \text { p. } 171-175\end{array}$ & $\begin{array}{l}\text { Glory...and now...: God } \\
\text { enduring all...plagal mode IV, } \\
\text { f. } 144-146 \mathrm{v}, \text { p. } 287-292\end{array}$ \\
\hline $\begin{array}{l}\text { The third Hour: } \\
\text { For the fear of the Jews.... } \\
\text { plagal mode IV, f. } 88-89 \mathrm{v}, \mathrm{p} \text {. } \\
175-178 ;\end{array}$ & $\begin{array}{c}\text { The third Hour: } \\
\text { For the fear of the Jews ... } \\
\text { plagal mode IV, f. } 146 \mathrm{v}-149 \text {, } \\
\text { p. } 292-297\end{array}$ \\
\hline $\begin{array}{l}\text { Before the honest crucifixion.... } \\
\text { plagal mode IV, f. } 89 \mathrm{v}-91, \mathrm{p} . \\
\qquad 178-181\end{array}$ & $\begin{array}{l}\text { Before the honest crucifixion.... } \\
\text { plagal mode IV, f. } 149-151 \text {, p. } \\
\qquad 297-301 ;\end{array}$ \\
\hline $\begin{array}{l}\text { Glory... and now...: When they } \\
\text { were dragging you to the } \\
\text { cross... plagal mode I, f. } 91 \text { - } \\
\quad 93, \text { p. } 181 \text { - } 185 ;\end{array}$ & $\begin{array}{l}\text { Glory... and now...: When they } \\
\text { were dragging you to the } \\
\text { cross.... plagal mode I, f. } 151 \text { - } \\
153 \mathrm{v}, \text { p. } 301-306 ;\end{array}$ \\
\hline $\begin{array}{l}\text { The sixth Hour: } \\
\text { These are the words of the Lord } \\
\text { to the Jews.... } \\
\text { plagal mode IV, f. } 93-95 \mathrm{v}, \mathrm{p} \text {. } \\
185-190 ;\end{array}$ & $\begin{array}{l}\text { The sixth Hour: } \\
\text { These are the words of the Lord } \\
\text { to the Jews ........... } \\
\text { plagal mode IV, f. } 153 \mathrm{v}-156 \mathrm{v} \text {, } \\
\text { p. } 306-312 ;\end{array}$ \\
\hline $\begin{array}{l}\text { The Legislators of Israel .... } \\
\text { plagal mode IV, f. } 96- \\
\text { 98, p. } 191 \text { - 195; }\end{array}$ & $\begin{array}{l}\text { Glory... and now...: Come you } \\
\text { crowds of Christ carrying.... } \\
\text { plagal mode I, f. } 156 \mathrm{v}-160, \text { p. } \\
\qquad 312-319 ;\end{array}$ \\
\hline Glory...and now...: Come you & The Legislators of Israel.... \\
\hline
\end{tabular}




\begin{tabular}{|c|c|}
\hline $\begin{array}{l}\text { crowds of Christ carrying.... } \\
\text { plagal mode I, f. } 98 \text { - 100, p. } \\
195-199\end{array}$ & $\begin{array}{l}\text { plagal mode IV, f. } 160 \text { - } \\
163, \text { p. } 319-325 ;\end{array}$ \\
\hline $\begin{array}{l}\text { The nineth hour: } \\
\text { It was scary to see.... plagal } \\
\text { mode III, f. } 100 \mathrm{v}-101 \mathrm{v}, \text { p. } 200 \\
-202 ;\end{array}$ & $\begin{array}{c}\text { The nineth hour: } \\
\text { It was scary to see.......mode III, } \\
\text { f. } 163-165 \text {, p. } 325-329 ;\end{array}$ \\
\hline $\begin{array}{l}\text { When they nailed the cross.... } \\
\text { mode II, f. } 101 \mathrm{v}-104 \mathrm{v}, \text { p. } 202- \\
208 ;\end{array}$ & $\begin{array}{l}\text { When they nailed the cross.... } \\
\text { mode II, f. } 165-169 \text {, p. } 329 \text { - } \\
337 ;\end{array}$ \\
\hline $\begin{array}{l}\text { Glory...and now...: Today he } \\
\text { hanged himself on the wood.... } \\
\text { plagal mode II, f. } 104 \mathrm{v}-106 \mathrm{v}, \\
\text { p. } 208-212 \text {; }\end{array}$ & $\begin{array}{l}\text { Glory...and now...: Today he } \\
\text { hanged himself on the wood.... } \\
\text { plagal mode II, f. } 169-171 \mathrm{v}, \mathrm{p} . \\
\quad 337-342 ;\end{array}$ \\
\hline $\begin{array}{l}\text { On the Third Sunday of the } \\
\text { Holy Lent, at the Sacrament } \\
\text { of Honest and the Life Maker } \\
\text { of the Cross, from the heavy } \\
\text { troparia of Sticherarion the } \\
\text { Old: }\end{array}$ & $\begin{array}{l}\text { At the Falling asleep of the } \\
\text { Most Holy Master, by the } \\
\text { Mother of God, Virgin Mary, } \\
\text { in the Sticherarion the Old, } \\
\text { Glory ... and now ..... on eight } \\
\text { modes, it starts from first } \\
\text { mode, having its Pa: }\end{array}$ \\
\hline $\begin{array}{l}\text { (from Litija) Glory ... and now } \\
\text {... Seeing your whole creature } \\
\text { crucified.... plagal mode I, f. } \\
\text { 106v - } 109 \mathrm{v}, \text { p. } 212-218\end{array}$ & $\begin{array}{c}\text { With God's ruling will... f. } \\
171 \mathrm{v}-177 \mathrm{v}, 342-354 ;\end{array}$ \\
\hline $\begin{array}{l}\text { Glory ....: Today the not closed } \\
\text { to me after being .. plagal } \\
\text { mode IV, f. } 109 \mathrm{v}-114 \text {, p. } 218- \\
\qquad 227 ;\end{array}$ & $\begin{array}{l}\text { Another troparion of the } \\
\text { heavy ones, on eight modes, at } \\
\text { the beheading of the Prophet } \\
\text { of the Forerunner and John } \\
\text { the Baptist, starts from the }\end{array}$ \\
\hline
\end{tabular}




\begin{tabular}{|c|c|}
\hline & first mode Pa: \\
\hline $\begin{array}{l}\text { At the Falling asleep of the } \\
\text { Most Holy Master, by the } \\
\text { Mother of God, Virgin Mary, } \\
\text { in the Sticherarion the Old, } \\
\text { Glory ... and now ..... on eight } \\
\text { modes, it starts from first } \\
\text { mode, having its Pa: }\end{array}$ & $\begin{array}{c}\text { From Litija } \\
\text { Today, the unrespectful kind.... } \\
\text { f. } 177 \mathrm{v}-183, \text { p. } 354-365 ;\end{array}$ \\
\hline $\begin{array}{l}\text { With God's ruling will... f. 114- } \\
\text { 118v, 227- 236; }\end{array}$ & $\begin{array}{c}\text { On the Third Sunday of the } \\
\text { Holy Lent, at the Sacrament } \\
\text { of Honest and the Life Maker } \\
\text { of the Cross, from the heavy } \\
\text { troparia of Sticherarion the } \\
\text { Old: }\end{array}$ \\
\hline $\begin{array}{l}\text { Another troparion of the } \\
\text { heavy ones, on eight modes, at } \\
\text { the beheading of the Prophet } \\
\text { of the Forerunner and John } \\
\text { the Baptist, starts from the } \\
\text { first mode Pa: }\end{array}$ & $\begin{array}{l}\text { (from Litija) Glory ... and now } \\
\text {...: Seeing your whole creature } \\
\text { crucified....plagal mode I, f. } 183 \\
\quad-187, \text { p. } 365 \text { - } 373 ;\end{array}$ \\
\hline $\begin{array}{c}\text { From Litija } \\
\text { Today, the unrespectful kind.... } \\
\text { f. } \mathbf{1 1 9}-\mathbf{1 2 2 v} \text {, p. } 237-244 ;\end{array}$ & $\begin{array}{l}\text { Glory ....: Today the not closed } \\
\text { to me after being .. plagal } \\
\text { mode IV, f. } 187-194 \text {, p. } 373- \\
387 ;\end{array}$ \\
\hline
\end{tabular}

From the analysis of the two manuscripts, the following observations can be drawn:

- in the manuscript of Gregory Protopsaltes, the tenth eothina in the sheet 71, is not over. From the sheet 71 
on the back, begins the eothina XI, the beginning of which is missing;

- at the sixth hour in the Friday of Passions, at Gregory Protopsaltes is troparion + glory .. and now ... + troparion; at Macarie troparion + troparion + glory ... and now ......, as it is in Triodion;

After the sticheras on Good Friday, at the two appears the scheme:

\section{Gregory:}

- Sticheras at the Falling asleep of Virgin Mary;

- at beheading of St. John the Baptist;

- on the third Sunday in the great Lent;

\section{Macarie:}

- stichera on the third Sunday in the great Lent;

- at the Falling asleep of Virgin Mary;

The conclusions that can be drawn are:

- The Sticherarion of Hieromonk Macarie is an intangible translation of Sticherarion Anthology, by Gregory Protopsaltes, this statement being supported by the presence of the same songs in the two manuscripts.

- Manuscript. BAR 1690 wasn't based on Manusc. EBE 1945- Sticherarion Anthology of Gregory Protopsaltes, but perhaps another copy because the order of the songs differs.

The sticheraric style is the old one, of Anastasimatarion and Sticherarion of Chrysaphes the New and the Sticherarion of Ghermanos Neon Patron, sung melismatically at the end of the 18th century. The old style is characteristic to the practice of beautification by which a melody is enlarged by the introduction of melodic formulas, non-alphabetic letters. 
The new sticheraric style is that of the stichera of Anastasimatarion and the Doxastarion of Petros Lampadarios. The „new” is given in comparison to the „old" Sticheraric style.

The songs of the old sticherarion, melismatically transcribed by the three teachers, were interpreted moderately melismatically (similar to the new Sticheraric style) until the beginning of the eighteenth century.

\section{Bibliography}

\section{a. Sources:}

1. Athens- National Library of Greece

2. Greek manuscripts: EBE 1945 (Anthology Sticherarion-new graphGregory Protopsaltes, beginning of the nineteenth century).

3. Bucharest - Romanian Academy Library

4. Romanian manuscripts: BAR 1690 (Sticherarion -Hieromonk Macarie, first half of the 19th century).

\section{b. Lexicons, dictionaries and catalogs:}

5. AlEXANDRESCU, Ozana, The catalog of 17th-century Byzantine musical manuscripts, Arvin Press Printing, Bucharest 2005.

6. DICTIONARY OF MUSIC TERMS, Scientific and Encyclopaedic Publishing House, Bucharest, 1984.

7. IONESCU, C. Gheorghe, The lexicon of those who over the centuries dealt with Byzantine music in Romania, Diogene Printing, Bucharest, 1994.

8. ȘTREMPEL, Gabriel, The catalog of Romanian manuscripts B.A.R. 1601-3100, vol II, Scientific printing, Bucharest 1983.

\section{c. Specialty literature:}

9. BRANiște, Ene, General liturgy vol. I., Publishing House of Dunarea de Jos Episcopate, Galați, 2002.

\section{d. Studies :}

10. BARBU-BUCUR, Sebastian, Filothei sin Agăi Jipei. Romanian psalm book, vol.III, The sticherarion in: Sources of the 
Romanian music. Documenta et Transcripta, vol. VII C, Bucharest, Musical Publishing, 1986.

11. BARBU-BUCUR, Sebastian, Presumptions about the ethnic origin of Chrysaphes the New in: Acta Musicae Byzantinae, vol. III, April 2001, Center for Byzantine Studies Iași.

12. KonstantinOU, N. Georgios Theory and practice of church music, translated into romanian by Adrian Sîrbu, Byzanton cultural Association, Iași 2012.

13.GHEORGHIȚĂ, Nicolae, Sunday Chinonic in the post-Byzantine period 1453-1821, Sofia Publishing, Bucharest 2009.

14. MoIsIL, Costin, Anastasimatarion of Hieromonk Macarie Introductive study, Byzantine Publishing, Bucharest, 2002.

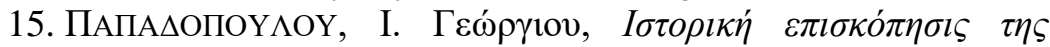

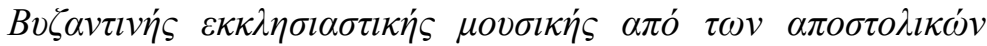

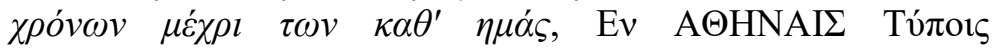

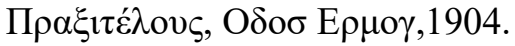

16. PANȚîRU, Grigore, The Notation and the ihos of Byzantine Music, Musical Publishing House of the Union of Composers, Bucharest, 1971.

\section{e. Web sources :}

17. Ecumenical Patriarchate, Gregory Protopsaltes the Byzantios, disponibil la http://www.ec-patr.net/en/history/gregorybyzantios.htm (accesat la data de 06.03.2019). 